\section{Breaking the boundaries of professional regulation: medical licensing, foreign influence, and the consolidation of homeopathy in Mexico}

\section{Rompendo as barreiras da regulamentação profissional: licenciamento médico, influência estrangeira e consolidação da homeopatia no México}

Received on 23 Feb. 2018.

Approved on 28 May 2018.

BERRONES, Jethro Hernández. Breaking the boundaries of professional regulation: medical licensing, foreign influence, and the consolidation of homeopathy in Mexico. História, Ciências, Saúde-Manguinhos, Rio de Janeiro, v.26, n.4, out.-dez. 2019, p.12431262.

Abstract

As doctors sought state support to regulate professional training and practice after Independence, Mexicans also developed different attitudes toward foreign ideas, influences, and professionals. Leveraging the allure of the foreign among Mexicans, homeopaths strategically used work, products, and organizations from abroad to establish their practices and fight changing professional policies in the country that threatened homeopathic institutions. Homeopaths inhabited the blurry and shifting boundary between professional and lay medical practice during the early Republican period, the Porfiriato, and the post-revolutionary era, and used the ambivalent feelings about medical licensing, and foreign influence in Mexican society to consolidate their position.

Keywords: homeopathy; medical profession; nationalism; Mexico; foreign.

Resumo

Após a independência do país, enquanto os médicos buscavam apoio do Estado para regulamentar o treinamento e a prática profissionais, os mexicanos desenvolveram atitudes diferentes em relação a ideias, influências e profissionais estrangeiros. Aproveitando o encanto dos mexicanos com o estrangeiro, os homeopatas usaram estrategicamente o trabalho, os produtos e as organizações de fora do país para implantar suas práticas e combater as políticas que ameaçavam as instituições ligadas à homeopatia. Os homeopatas ocuparam a barreira nebulosa entre as práticas médicas profissional e leiga no início do período republicano, no Porfiriato e na era pós-revolucionária, usando sentimentos ambivalentes sobre licenciamento médico e influência estrangeira para consolidar sua posição.

Palavras-chave: homeopatia; profissão médica; nacionalismo; México; estrangeiro. 
$\mathrm{O}$ $\mathrm{n}$ the back cover of a special issue of Acción Médica, the Mexico City Union of Medical Doctors published a cartoon containing a scathing critique of homeopathy and its institutions in Mexico. Fortunetellers, witches, astrologers, and alchemists literally and metaphorically surround a full auditorium where homeopaths are holding a meeting; the lecturer at the podium and posters hanging in the background present homeopathic ideas as wrongfully using and criticizing contemporary medical concepts. In response to the scene, a couple of doctors in the audience comment in obviously broken Spanish: "Ho in Mexico los homeópatas no saber medicina." This cartoon was an open criticism of the 1935 Pan-American Homeopathic Congress in Mexico City (En 1935..., 1935, p.12). The members of this union believed foreign influence could sway the Mexican government into supporting homeopathy and improving its position among national medical institutions, and consequently depicted homeopaths as practitioners who ruptured the boundaries of professional medicine, attaining this status in response to state support and strategical manipulation of Mexican interest in foreign ideas.

By the mid-1930s, homeopaths were a consolidated medical group in Mexico. In 1895 they organized the National School of Medicine and Homeopathy (Escuela Nacional de Medicina y Homeopatía, ENMH), a school funded by the federal government, as well as the privately-funded Free School of Homeopathy (Escuela Libre de Homeopatía, ELH) in 1912. Government institutions ratified the official status of these schools in the early 1930s. The Secretariat of Public Education (Secretaría de Educacíon Pública, SEP) inspected the facilities and programs to make sure that students were receiving high-quality medical training. This office then validated their diplomas and the Department of Public Health (DPH) registered them, granting graduates official status as medical practitioners. This made registered homeopaths legally eligible for leadership roles in public and private medical institutions reserved for registered practitioners. By the mid-1930s, ten percent of registered doctors were graduates of these two homeopathic schools. The union's critique reflected growing concerns among health authorities and university physicians about the increasing recognition of homeopathy and its institutions in Mexico. But why did the union use the voice of an English-speaking homeopathic doctor to undermine the homeopaths' medical knowledge? Homeopaths had participated in a Pan-American and even an international meeting in 1929, with few public expressions against homeopaths and their practice. Furthermore, homeopathy came to Mexico in the early 1850s as a European medical system introduced by Spanish physicians into a young, independent country that struggled to find internal stability and national identity. As the practice of homeopathy grew around the globe as well as in Mexico during the nineteenth and early twentieth centuries, Mexican physicians questioned the system and its practitioners' origin in response to their changing attitudes toward international influences. The critical foreign homeopath on the back cover of the magazine therefore represents the response by domestic physicians to a growing community of homeopaths in the country, one with increasing ties to and support from foreign actors.

Mexican attitudes to foreigners throughout the nineteenth and twentieth centuries shifted in response to Mexico's struggles to position itself within the global political economy; historian Jürgen Buchenau identifies three distinct periods (Buchenau, 2001). 
During the first five decades after gaining independence (1821), Creoles and Mexicans developed strong feelings against foreigners in response to outside interventions. AntiSpanish attitudes evolved from the marginalization of Creole elites as the Bourbon reforms were implemented during the late eighteenth century, anti-American feelings resulted from the Mexican-American War (1846-1848) and the losses of Texas and California to Mexico's northern neighbor, and the French intervention (1861-1867) and the imposition of a European emperor combined to prompt anti-French sentiments among Mexicans. The triumph of liberals in the late 1860s and the political stability of Porfirio Díaz's thirty-year dictatorship (1875-1910) attracted foreign investment, welcoming immigration from European and neighboring countries. The Porfirian elite created a legal framework and programs to populate Mexico's rural landscape and to recruit skilled workers and professionals to emergent and developing industries. The Mexican Revolution (19101920) exposed the flaws in the political economy of the Porfiriato and forced Mexicans to look inward, recognizing the privileges foreigners had enjoyed. The new Constitution of 1917 (which protected national lands and regulated labor) and nationwide programs to unify the nation racially and culturally are two examples of strategies post-revolutionary governments used to undermine and restrict foreign economic and cultural influences. Over two centuries, Mexico struggled between welcoming foreign ideas, labor, and investment to achieve fast-track modernization and coming to terms with the social, cultural, and economic consequences of foreign influence.

This ambivalence shaped Mexican doctors' attitudes toward medical knowledge imported from abroad, practitioners trained overseas, and sanitary campaigns designed with limited domestic participation. In the Viceroyalty of New Spain, the Protomedicato (colonial medical board) controlled academic medicine by regulating a medical curriculum modeled on those of Europe and by establishing licensing requirements based on birthplace, race, and class (Hernández Sáenz, 1997). Meanwhile, most of the population shared traditional European and native American medical knowledge and practices in their private and public lives, challenging academic medicine in the late colonial and early Republican periods (for other Latin American regions, see Palmer, 2003; Sowell, 2001). Along similar lines, sanitary campaigns implemented European approaches and technologies such as quarantines and vaccination, which prompted debate and reaction in academic circles and among the public (Few, 2010; McCrea, 2010). In 1833, Mexican physicians attempted to professionalize their training and practice by creating the National School of Medicine and the Superior Board of Health and by implementing nationalist licensing criteria. Yet instability delayed the consolidation of the medical profession, and permitted the presence of non-academically-trained practitioners from Mexico as well as abroad (Agostoni, 2007; Carrillo, 1998; Hernández Sáenz, 2018). During the Porfiriato, domestic doctors welcomed European medical science and practitioners, using them to consolidate national medical institutions and create new ones, sanitize the city, and position it among the cleanest and healthiest in the world, but also demanded a state role in regulating professional training and practice (Agostoni, 2003; Priego, 2009). While the medical profession remained open to foreign influences and support in medicine and public health after the 1910 Revolution, nationalist doctors questioned and challenged foreign influences and intervention in 
social, cultural, professional, and political spheres (Birn, 2012; Cueto, 2007; Solórzano, 1996). The historiography has mostly focused on public health campaigns to examine the negotiations between international and foreign actors regarding the transfer of knowledge, technology, and staff, tangentially examining tensions and frictions between foreign and Mexican doctors; international influence on and nationalist attitudes toward professional licensing as the focus of historical analysis have not yet been utilized in this area.

The professionalization of homeopathy in Mexico offers a useful lens for exploring this question. The history of this practice spans Buchenau's three periods, providing an opportunity to compare the dialectics between changing nationalist attitudes and general trends of international influence over the Mexican medical profession. As in other countries, homeopaths in Mexico became the largest group of medical practitioners to challenge the hegemonic model of medical professionalization (Carrillo, 1998; Haller, 2005, p.39-68; Jütte, 2006). The various popularization strategies and professionalization models they used adapted to and challenged contemporary national trends, inhabiting the boundaries of professional medicine. Homeopaths popularized their system following the Enlightenment ideal of democratizing knowledge, aligning with liberal ideas of unrestricted professional practice in the mid-nineteenth century (Hernández Berrones, 2017). They complied with training and licensing requirements and obtained state support to create the ENMH, agreeing to a greater government role in regulating professional training and practice in the last quarter of the century (François-Flores, 2007). They organized free medical schools which were independent of state regulation, promoting access to professional medical education for Mexicans from the lower socioeconomic classes after the Revolution of 1910 (FrançoisFlores, 2004). Over a century, homeopaths in Mexico strategically used the foreign origins of homeopathy and their ties to foreign practitioners and institutions (in coordination with other strategies) to strengthen their position in the national medical profession. Domestic trends and international connections combined to solidify homeopathy within the national landscape of health providers.

This paper examines the overseas networks of Mexican homeopaths and their impact on the consolidation of homeopathy in Mexico. It highlights the relevance of Mexican physicians' attitudes toward foreign medical knowledge, practitioners, and products in constructing a national medical profession which includes homeopathy. In adapting to liberal and state-regulated models of health provision and professional organization, homeopaths developed contrasting yet effective strategies that opened a space among patients and state institutions to them in Mexico as they did in few other places worldwide in the nineteenth and early twentieth centuries, i.e. Brazil and India (Hausman, 2002; Weber, 2016). Mexican homeopaths strategically used their ties with foreign work, products, and organizations to adjust to the changing political environment that influenced professional regulations in the early Republican period, the Porfiriato, and the Revolution. The first section provides an overview of licensing regulations and policies related to the practice of medicine by foreigners in Mexico, from Independence to the post-revolutionary period. The second section examines the use of contradictions between these regulations and policies by homeopaths to obtain medical licenses. We then examine their promotion of foreign knowledge and products to expand their clientele. The last section investigates 
the international networks of homeopaths and shifting government attitudes in response to these international connections after the Revolution. Regardless of shifting nationalist attitudes and growing government control over professional medicine, homeopaths in Mexico leveraged foreign influence to advance their position in the medical profession and among patients.

\section{Drawing the professional boundary between foreign and domestic medical practitioners}

The regulation of medical practice was an extension of the regulation of professional practice in post-independent Mexico. Since the nineteenth century intellectuals and lawmakers had favored the liberty of professional practice and reflected this view in constitutional law, but corporate professional bodies and government offices saw a need to place limits on professional freedom, for economic, administrative, and social reasons. When the liberals triumphed in 1857, they produced a Constitution which granted freedom of teaching (Article 3) and professional practice (Article 4). Article 3 stated that legislation would determine which professions required practitioners to hold a diploma, but Article 4 acknowledged each individual's right to pursue any profession, industry, or work. After the Revolution, the 1917 Constitution preserved these articles and their inherent contradiction. To confuse things even more, corporate bodies and professional institutions established professional standards that state governments utilized to formulate legal standards and codes which ran counter to the Constitution. The history of professions in Mexico before the 1942 Law of Professions is a history of the tensions generated by constitutionally-granted professional freedom and government policies and regulations to control professional practice. These contradictions framed policies and laws which granted or denied physicians trained in Mexico or abroad the right to practice.

After Independence, post-colonial institutions legislated using criteria established by medical institutions and doctors' views on foreign physicians. Following the anti-Spanish sentiment of the early independent period, the medical school and board of health required foreign practitioners to document their medical education abroad, two years of residence in the country, and their ability to speak Spanish (Barrera, 10 Mar. 1841). Immediately after the Mexican-American War ended, then-president Santana issued regulations that relaxed restrictions on professional practice by foreigners living in the country (México, 1876). Despite the professional liberalism of the 1857 Constitution, local legislation assumed the medical institutions' licensing criteria. The 1871 Penal Code and the 1891 Sanitary Code, for instance, penalized practice by unlicensed physicians (Agostoni, 1999, p.16; Álvarez, 1960, p.373-379). Without legal consistency, complying with professional regulations became a status symbol rather than a professional control, and licensed physicians discriminated against non-complying practitioners during the Porfiriato. In their critiques, the Porfirian medical elite associated unlicensed practitioners with their European origin, accusing them of lacking diplomas, paying for false ones, or lacking adequate training despite "official" documentation (Agostoni, 1999, p.17, 22-25). Doctor Eduardo Lavalle y Carbajal noted an increasing presence of physicians trained in the United States in the late Porfiriato. In 
his words, low-quality foreign schools, "such as the ones in the United States ... turned the illiterate son of a Central American ranchero into a physician in one or two years [or if schools] did not even have facilities, they communicated with their candidates by mail" (Lavalle y Carbajal, 1913, p.170-171). Porfirian doctors, however, were ambivalent about foreign physicians, as they also acknowledged high-status foreign universities and welcomed their graduates. Legislators suggested fewer restrictions on bearers of foreign diplomas in a proposal to regulate professional practice in 1901 (Lavalle y Carbajal, 1913, p.185), and when it was established in 1910, the National University of Mexico revalidated numerous foreign diplomas (Revalidación..., 1911).

The nationalism infused by the Revolution brought back policies and regulations against the professional practice of foreigners. Felix Palavicini, the Minister of Public Instruction, asked the university to enforce the Penal Code and prosecute practitioners holding foreign degrees who illegally offered their services in Mexico City in 1915 (Palavicini, n.d.). The 1917 Constitution introduced new restrictions on the activity of foreigners in the country (Yankelevich, 2004, p.693-700), though it did not alter Article 4. Nationalist physicians renewed their critiques of foreign physicians, asking for regulations to level out professional competition. In a speech to celebrate the inauguration of the Mexican Medical Association, Doctor Gregorio Mendizabal (1920, p.23) welcomed legal and honest competition from American physicians, but called for the use of all legal means to fight dishonest competition. In the medical school journal, Doctor Daniel Gurría Urgell (1924, p.2-3) described foreign medical practitioners as the most prominent enemies of the national medical profession because they did not always comply with the national licensing model, and when they did they usurped titles, such as membership in the Faculty of Medicine. He also accused them of looking down on domestic physicians, while he believed that the foreigners' own practice was inferior. Finally, Gurría Urgell blamed Mexican patients for their "cult of foreignness," seeking services from foreign physicians over Mexican doctors. The nationalist discourse of physicians was intended to shape the opinion of medical students and practicing physicians who would become government officers and consequently formulate and implement legislation limiting the practice of foreign physicians.

The National University and DPH formulated regulations in the early 1920s which remained in place until the Mexican congress signed the 1942 Law of Professions. The university became responsible for the curricula of professional schools and for issuing professional diplomas in Mexico City, but had no clear policies regarding foreign diplomas. In line with the medical elites' view on foreign medical practitioners, the university board acknowledged the need to revalidate diplomas from famous universities (such as Salamanca, Oxford, the Sorbonne, or Harvard) but expressed doubts about diplomas issued by private universities or universities "via correspondence" (Segunda Sesión, 20 Jan. 1922). The board ruled that the university would issue diplomas through revalidation only when its professional schools examined petitioners (Secretaría..., 30 May 1922). The university would acknowledge diplomas issued by specific institutions (i.e., accreditation) if it deemed the institution in question worthy of credit, if any of the states of the republic accredited these diplomas, or if Mexico had reciprocity treaties relating to professional practice with the issuing country. Two years later, the university suspended accreditations and pushed for 
revalidations in order to reciprocate the conditions other countries imposed on Mexican professionals and to balance out the Mexican popular preference for foreign professionals (Ocaranza, Cuevas, Nov. 1925). Throughout the 1920s and 1930s, different professional groups presented various proposals to congress to regulate Article 4 of the Constitution (Reglamento..., 1922, p.26; Juárez Ochoa, López Soto, Borja, 4 Nov. 1927; Liga..., 20 Feb. 1934; Reglamentación..., 1937, p.75). All included measures for foreign diplomas which resembled those stated by the National University, and SEP was in line with this trend. When it assumed control over revalidation in 1938, it maintained the university's policies (Vázquez Vela, 14 Feb. 1938). Meanwhile, the DPH reinforced the medical registry as a licensing tool. In the early 1920s it took the lead in deciding whether to license a physician with a foreign degree, given the university's ambivalence about foreign diplomas (Aviso..., 12 June 1923). With the university's clear policies and regulations related to foreign medical diplomas, the DPH registered all foreign diplomas revalidated by the National University or the states.

The consolidation of professional medical licensing regulations aligned with perceptions among university physicians about the growing presence of foreign doctors in the domestic medical marketplace. These doctors believed that the foreigners took advantage of the cult of foreignness in Mexico to cut regulatory corners and obtain licenses. As a result, the medical authorities reinforced policies and regulations to limit the practice of foreign physicians, but to little effect. As we shall see in the case of homeopaths, practitioners benefited from the cult of foreignness and used it to convince authorities without medical backgrounds, bending the policies and laws that denied licenses to homeopaths. This in turn contributed to the public image of homeopaths in medical circles as a threat to the modernization of the medical profession.

\section{Breaking the boundaries of medical licensing}

The foreign origin of homeopaths and their endorsement of a German medical system helped to portray homeopathic practice as alien and irregular in the mid-nineteenth century. As they aligned with French medicine, Mexican physicians distanced themselves from German medicine (including homeopathy). Manuel Eulogio Carpio, an influential physician in the 1830s and 1840s, associated homeopathy with high dilutions and doubted its therapeutic action. He maintained that homeopathic globules lacked any real physical effect, and attributed successful outcomes to the body's natural ability to heal itself and homeopaths' ability to influence the imaginations of their patients (Martínez Cortés, 1997). In addition to the limitations of practicing an unwelcome medical system, the first homeopaths in Mexico had to overcome their foreign status to comply with professional regulations. Ramón Comellas and José Carbó (from Spain and Cuba, respectively) obtained authorization from "the Supreme Government" as a result of their successful medical practice (Respuesta..., 1855; Carbó, 30 Jan. 1854). While the board of health accepted the resolution for Comellas because he presented his foreign medical degree and was examined by the medical faculty of the state of Veracruz, it hesitated to authorize Carbó, whose multiple requests, supporting documents, foreign credentials, and endorsements, changed 
every time they were resubmitted (Solicitud..., Aug. 1871). Two other foreigners, Narciso Sanchiz and Rafael Navarrete (again, from Spain and Cuba) requested unconventional licensing procedures, such as written examinations or examinations on homeopathy rather than medicine and surgery (Sanchiz, 18 Jan. 1855; Navarrete, n.d.). In the mid-nineteenth century, the board of health made sure the medical registry indicated which physicians had obtained their licenses through diplomas issued elsewhere, highlighting their foreign origins (Médicos..., 25 Feb. 1859).

Despite professional liberalism during the Porfiriato, Mexico attracted very few foreign homeopaths. The most iconic of these was Juan Antiga y Escobar; a native of Cuba and graduate of the University of Havana, Antiga came to Mexico in 1896 with a Cuban medical diploma (Delgado García, 2005). He received a diploma from the ENMH in 1901, although the 1907 medical registry did not include him as a homeopath or physician with foreign credentials (Lista..., 1907). Just as Lavalle y Carbajal had stated in his complaint, Antiga received diplomas from several US colleges, including Thompson Medical College in Denver in 1904, the American Postgraduate School in Chicago in 1905, and Doctor White's Clinic in Los Angeles, California in 1906. He used these degrees to advertise his services and products in La Propaganda Homeopática, a journal he founded in 1900. The presentation of foreign credentials by Antiga and other homeopaths embodied the fears of Mexican physicians during the Porfiriato. Their ads contributed to the widespread perception that homeopathic credentials did not comply with professional regulations; although Antiga's foreign diplomas did not, his homeopathic degree did.

Without a diploma from a national medical school, the sanitary board rarely registered homeopaths with foreign degrees during the Porfiriato and after the Revolution; only three cases made it to the registry. Teófilo Olliver Ortiz illustrates the shifting policies and regulations of the period (Registro..., n.d.). Olliver came to Mexico in 1905 and obtained his diploma from the Homeopathic Institute of Colombia in 1906. A decade later, perhaps in response to Palavicini's call to crack down on foreign practitioners, he asked the ENMH to revalidate his diploma. The vice dean of the school, Doctor Luis Porragas, denied this request, arguing that Ollivier's coursework was not the same as that offered by the homeopathic school (Porragas, 10 Mar. 1914). Additionally, Porragas expressed his concern with "some institutes granting diplomas with examinations by correspondence." In 1920, perhaps in response to Pruneda's call to update the medical registry, Ollivier had his foreign diploma registered. This case illustrates how inconsistent policies kept doctors with foreign professional degrees out of the medical registry - or accepted them. These practitioners looked for ways to obtain licenses whenever policies or new legislation permitted, as suited their own professional trajectories.

Sometimes homeopaths used the "cult of foreignness" to bend regulations, while others pursued convoluted (albeit legal) paths. For instance, in 1922, the National University board and Porragas (who by that time was dean of the university's school of homeopathy) allowed Aliber García to present a general exam of incorporation to the Faculty of Homeopathy of Mexico because he had studied at New York University and the University of Chicago (García Treviño, 6 Oct. 1923; Porragas, 6 Oct. 1923). The school allowed this procedure despite school regulations requiring exams on each particular subject of the curriculum. 
García did not pass the examination, and authorities required him to do coursework for one year. Six months later, he requested his general examination again, passed it this time, and received his diploma; the DPH registered his diploma five years later. His case evidences the weight of foreign medical diplomas in decisions related to licensing. In 1925, William A. Jemmal preferred to revalidate his foreign diploma from the New York Homeopathic Medical College at the Yucatán School of Homeopathy Medicine, which was founded in 1922, and then have it registered by the DPH (Registro..., n.d.). Whether this revalidation implied examination is unclear.

After the 1850s, foreign homeopaths in Mexico found ways to circumvent professional legislation which was already contradictory. They obtained medical licenses through political influence, traditional non-homeopathic credentials, shifts in policy, the cultural weight of specific foreign universities, or legal inconsistencies, despite efforts by medical schools and health institutions to implement professional policies and regulations during the Porfiriato and after the Revolution. These and similar cases may have helped formed the opinion of leaders such as Lavalle y Carbajal, Mendizabal, and Gurría, and triggered more restrictive policies on revalidation of foreign diplomas by the university and registering practitioners with the DPH. Besides the origin of their degrees, homeopaths also engaged with foreign medical knowledge, therapies, and products in a way that undermined the values of the medical profession.

\section{The cult of foreignness in Mexican homeopathic practice}

The professionalization of homeopathy took place alongside the strengthening and consolidation of medical institutions in the 1870s and the Porfiriato. At this time, Mexican homeopaths split into two groups. Licensed homeopaths aligned with the values and practices of the medical profession, including compliance with professional regulations, a reserved attitude toward unexpected healings and promising therapies, and a clear distinction between professional duties and commercial endeavors (Agostoni, 1999, p.2526). Unlicensed homeopaths endorsed professional freedom, though they followed the same strategies of professional organization advocated by their licensed peers, such as the organization of societies and publication of journals. Both groups promoted homeopathy by engaging with foreign medical knowledge and making it accessible to the Mexican public. The politics of medical professionalization, however, mediated this engagement. In the 1870s and 1880s, licensed homeopaths validated homeopathy through their own scientific analyses and experiments. Later in the Porfiriato, an important group of licensed homeopaths and many unlicensed ones went back to promoting homeopathy with ideas and products from abroad, particularly from the US. This section examines this trend in the late nineteenth century, when Latin American nations opened their doors to international trade. The industrial revolution and its wealth of commodities (including medical merchandise) increased homeopathy's presence in Mexican markets in the second half of the nineteenth century. The elites of Mexico were dazzled by the application of science and the utility of its products (Bauer, 2001, p.129-164; Bunker, 2012), and transformed their lives, homes, environment, and nation with imported goods that symbolized modernization. A group 
of homeopaths risked their professional image to take advantage of this cult of foreignness, as the Mexican doctors called it, in order to commercialize medical commodities, expand their clientele, and carve out a larger space for homeopathy in the medical marketplace.

Licensed physicians were concerned with medical knowledge that had been imported without proper examination. In his 1861 critique of homeopathy, Gabino Barreda (1861) used positivism to disentangle (as he described it) the fallacies of homeopathy and expose them to people who used the therapy in a misguided manner. Along similar lines, Mexicans were expected to evaluate medical theories through experimentation (systematic testing of logical consequences from a given theory, as opposed to experiences), in an arbitrary collection of successful medical interventions. Given the relatively new presence of homeopathy in the country, the proliferation of Spanish and Cuban homeopaths, and their association with licensing procedures that avoided examination in the 1860 s and 70s, licensed Mexican physicians believed that the public might accept foreign medical influences without questioning their validity through rational examination.

Homeopaths were ambivalent about this perception. Many licensed practitioners sought to change it, while most unlicensed ones continued to promote works from abroad, and a few engaged in both practices. Licensed homeopaths transitioned from using European homeopathic authorities to formulating their own arguments regarding the positive foundations of homeopathy. El Propagador Homeopático published three lectures by French and Spanish homeopaths from 1870 to 1874. After an internal conflict between licensed and unlicensed homeopaths, the journal changed its name to La Reforma Médica and moved to publish only work by new members, most of them Mexican. Pamphlets and books written by domestic homeopaths increased from three in the 1870s to nineteen in the 1900s (Cedillo, 1919). By the late nineteenth century, licensed homeopaths had aligned with the scientific and nationalistic values of the medical profession. Their publications suggest they became producers of homeopathic knowledge rather than consumers of foreign homeopathic ideas. They were, however, aware of the "cult of foreignness" among Mexican patients, and many of them continued translating foreign authors (mostly from the United States). During the 1850s, many homeopaths translated famous European homeopathic domestic manuals originally written in English, French, or German into Spanish (Hernández Berrones, 2017, p.578). Others, like Juan N. Arriaga, expanded the original sources to academic works by US homeopaths. In 1894, Arriaga published his first translations as monographs and a series of partial deliveries in La Homeopatía. Among the authorities he translated were E.B. Nash, Lamoument, Viliechauvaix, W.A. Dewey, E.B. Nash, J.H. Clarke, P.W. Shedd, and H.C. Allen (Cedillo, 1919). Luz Arriaga, Juan's wife, was also a very active translator; in just two decades, the two Arriagas translated thirteen texts that included dictionaries, homeopathic repertories, domestic manuals, clinical manuals, gynecological treatises, and essays, as well as many articles published in La Homeopatía. Many other licensed homeopaths like Arriaga translated, such as Francisco Castillo, Higinio Pérez and Juan Antiga, as well as unlicensed ones like Manuel Córdova y Aristi.

This eclectic attitude toward international medical influences can also be seen in homeopathic publications, where the link between academic discussion and commercial promotion began to blur. During the Porfiriato, La Homeopatía and La Propaganda 
Homeopática published both original works by Mexican homeopaths and translations of foreign homeopathic sources. The authors and translators in La Homeopatía tended to be licensed homeopaths, although both publications had a mixed team of writers and sponsors. These journals also advertised medical and homeopathic products. La Homeopatía had an academic profile, and only published information about homeopathy without crossing the boundary between commercial sponsorship and the journal's medical bent. La Propaganda Homeopática became a commercial enterprise, publicizing a wide variety of therapies and products sold by the journal's editor, Juan Antiga.

Antiga traded in a wide variety of foreign therapeutic systems and products. He was a therapeutic explorer, and homeopathy was a stepping-stone on the way to his therapeutic eclecticism. After he graduated from the ENMH in Mexico, he became a loyal defender and promoter of homeopathy, writing several articles on how homeopathic practitioners needed to closely study Hahnemann's Organon and Materia medica, and advertising homeopathic services in Spanish, English, and French (Antiga, 1904; Doctor..., 1904; Gran..., 1904). After traveling to the United States to study Thomsonianism, he began to advertise a wide array of therapeutic products. To support this transition he moved away from homeopathic exclusivism, arguing that "the medical school of the future" would teach its students to use different types of effective therapeutics (Antiga, 1906). Antiga's entrepreneurial activities in medicine began as pharmacy owners and promoters of new medications advertised their drugstores and products in La propaganda. Advertisements for José Uihlein's Drugstore, The Great Secret for the Dressing Table: Oriental White, The Anti-Mercurial Chemical Co., and Charles Mearchand's Hydrozone appeared every month in the journal, but none were directly associated with the journal's director. The July 1904 issue was the first time Antiga was featured as an agent for several products and drugstores including Luyties Homeopathic Pharmacy Co. in St. Louis, Missouri, Thompsonian medications, and Dunham's Homoeopathic Drugstore in New York.

Antiga's sale of The twelve tissue remedies of Schussler exemplifies the path from acknowledgment of foreign authority to commercial profit which so concerned university physicians. Manuel Córdova y Aristi advertised his translation of Boericke and Dewey's The twelve tissue remedies of Schussler in La Propaganda Homeopática in July of 1904. After consulting with J.H. Smithson, the purported introducer of this approach in the United States (Una carta..., 1905, p.9-10), Antiga was convinced of the effectiveness of these remedies in treating debilitating diseases, and began to commercialize a "systematic and practical course of Biochemistry" based on them (Curso..., 1905, p.16; Antiga, 1905, p.3-5). After traveling to Chicago in 1905, Antiga imitated medical advertising in the United States, using "nervous weakness," the malady of modernity, as a catch phrase to advertise invigorating therapies (De regreso..., 1905, p.4; No un alivio..., 1905, p.16; De la Peña, 2003, p.89-136). His wide-ranging therapeutic eclecticism in the treatment of weakness can be seen in the 27 different approaches he offered at a clinic in 1907, which included electrical homeopathy, alkaloids, psychotherapy, animal magnetism, hypnotism, massage, chromotherapy, hydrotherapy, osteopathy, and chiropractics (Clínica..., 1907). Advertisements for these therapies and many other products appeared intermittently until Antiga left the country in 1912 and ceased publishing the journal. Over this eight-year 
period, Antiga became an eclectic and entrepreneurial homeopath who profited from every therapeutic system or remedy he learned. He promised his prospective patients that he would treat their chronic and weakening diseases and restore their health through natural means, and other homeopaths did the same. In moving toward therapeutic eclecticism, homeopaths exploited the cult of foreignness during an era when foreign technologies were being adopted and health commodified.

Entrepreneurial homeopaths, their translations, and their products gained broader visibility in the Porfiriato. Homeopathy was so popular that Doctor Eduardo Manuell (1912) identified practitioners as an example of the damage professional liberty did to the nation. He believed liberalism restrained national medicine from delivering on its promises to transform Mexico into a healthy nation. In his view, liberalism allowed unqualified practitioners to evaluate the scientific value of medical theories and therapies, use their insight indiscriminately with patients, and turn healing into a profitable business, and he believed that homeopaths were a clear example. While most licensed homeopaths in the Porfiriato aligned themselves with the values, practices, and regulations of the medical profession, those who did not engaged in public activities which led licensed doctors to criticize them but at the same time attracted patients. The cult of foreignness gave homeopaths an advantage in regulatory terms, because even though licensed doctors fought against their acceptance, the rest of the population including presidents and authorities had their support. Mexican society's ambivalent view of foreign medical influence led the homeopaths who had graduated from the ELH to seek international support in order to gain the upper hand in domestic professional disputes.

\section{International support and the consolidation of Mexican homeopathy}

After the Revolution, the relationship between Mexican homeopaths and the international homeopathic community changed. Instead of importing novel therapies and products, a new generation of homeopaths looked for support from foreign homeopathic organizations. Professional liberalism, ineffective licensing regulations, and the official recognition of homeopathy during the Porfiriato led Mexican homeopaths to establish a professional relationship with homeopathic associations abroad. After 1910, the emergence of homeopathic free schools, the instability of ENMH as an official institution, the enforcement of medical licensing by the DPH, and the National University's neutral position on private school diplomas led homeopaths to seek support and political action from the international homeopathic community. This support came in the form of international meetings held in Mexico City, and formal requests to send Mexican representatives to international meetings. International meetings held in Mexico helped shift official attitudes toward homeopathic institutions in the late 1920s and mid-1930s, consolidating both schools as official institutions. Yet official recognition did not carry sponsorship, and governments in the 1930s denied support to attend international homeopathic events.

Members of the first homeopathic societies in Mexico established relationships with important representatives of homeopathy abroad during the nineteenth century. Marqués de Núñez and Joaquín Hysern in Spain, Carol Dunham in New York, and León Simón in 
France were members of the Mexican Homeopathic Institute (1869-1875) while it operated (Fuentes y Herrera, 1872). When Antiga and Arriaga brought homeopathic societies and journals back to social life in the 1890s, they exchanged publications with homeopathic groups abroad. La Homeopatía's News, Necrology, and Bibliography sections, as well as other dedicated articles, kept readers informed about the progress of homeopathy in countries such as Colombia, England, Guatemala, Holland, India, Italy, Spain, the United States, and Uruguay, as well as international congresses and universal expositions, international homeopathic directories, new and ongoing local and foreign homeopathic publications, and new, dismissed, and deceased members in the country and abroad. Readers also learned that Mexican homeopaths rarely contributed to international homeopathic journals, became members of foreign homeopathic societies, added foreign homeopaths as members of the Hahnemann Society, or participated in international meetings. Mexican homeopaths and patients consumed information about international networks of homeopaths in the late nineteenth century but did not participate, with a few exceptions. Fuentes y Herrera, González, and Arriaga submitted papers to international meetings in the Porfiriato, but it is unclear whether they attended (Fuentes y Herrera, 1876; González, 1891; Arriaga, 1911); Arriga's translations were displayed at the 1904 World's Fair in Saint Louis (CNM, 1904, p.78).

Homeopaths lamented the meager presence of Mexican homeopaths in international meetings. Antiga asked president Díaz for support in order to attend international meetings in 1906 and 1910, citing Arriaga, other homeopaths, his work in promoting Mexican homeopathy abroad, NHSM and its program's high international standing, and invitations by foreign homeopathic institutions such as the American Institute of Homeopathy (Antiga, 1909, p.54 -60). The president, however, did not respond favorably. With little support and on the eve of revolution, homeopaths significantly decreased their publishing activities and stopped participating in international meetings during the 1910s.

Even so, members of two homeopathic groups that emerged in the 1920s achieved what their predecessors could not attain. Beginning in 1924, faculty from the school of homeopathy in Yucatán and graduates of the ELH read papers at international meetings of the Liga Medico-homeopática Internacional (LMHI), and a few years later they held leadership positions (Transactions..., 1927, p.X). They also participated in or attended the Quinquennial International Congresses in 1927 and 1932 (Transactions..., 1927, p.100, 262, 479; Dixième Congrès..., 1932). Alongside their participation in international meetings, ELH graduates found a publishing venue in the US-based journal The Homeopathic Recorder. Beginning in 1929 with works authored by Higinio G. Pérez, the dean of ELH, the journal published articles by ELH graduates until the early 1940s (Panos, Desrosiers, 1989). By the late 1920s, recognition from the international homeopathic community was sufficient for Mexican homeopaths to host international meetings. These meetings, in turn, helped accelerate the ongoing process of legitimizing the ELH and its graduates in Mexico.

This situation was beneficial for the school. After the Revolution, the establishment of numerous free schools in Mexico City revived tensions caused by the ambiguities of professional regulation. The National University and DPH did not acknowledge ELH's official status; according to health regulations, graduates had to advertise their services as 
practitioners without a diploma. Yet this was unconstitutional, and graduates fought via legal and political means for their right to work (François-Flores, 2004, p.81-122). After the chaotic presidential succession of 1928, Free School of Law graduate Emilio Portes Gil (1928-1930) was interim president, and Ezequiel Padilla (an alumnus of the same school) was appointed to the Secretariat of Public Education. This agency took charge of regulating professional education a year later, relieving the National University of this duty, and in the process the Mexican government granted official status to free schools. How did the international networks and meetings of ELH graduates contribute to this outcome?

In response to the call by US homeopaths in the 1920s to organize "leagues" to promote homeopathy around the world, Mexican homeopaths created the Liga Homeopática Mexicana in 1928 (Vinyals, 1929, p.16; Liga..., 9 Apr. 1929). In 1929, the Liga organized the LMHI International Congress in Mexico City, and the organizer, Higinio Pérez, asked interim president Emilio Portes Gil for support in terms of facilities to receive homeopaths from abroad, organizing the meeting, and licensing ELH graduates (A los señores..., 1928, p.23; Congreso..., 1929, p.42; Sindicato..., 1929). The DPH director suspended the application of sanitary regulations which required an official medical diploma while ELH graduates asked the university to revalidate their diplomas. Portes Gil also halted the scheduled closure of the National Homeopathic Hospital and ordered it to be renovated in response to the director's request to have the hospital in good conditions for the meeting (Hospital..., 1929). National mobilization, international support, and presidential willingness combined to make the LMHI International Congress a success and help shift national policies toward free medical schools. In 1930, Portes Gil signed an act that acknowledged the official status of private schools (Mexico, 1929) and ELH graduates entered the medical registry, although the school's official status remained contested (Registro..., n.d.).

Presidents after Portes Gil who were advised by university physicians continued the Porfirian trend after 1929, denying assistance so that ELH graduates could attend international meetings. For instance, Eliud García Treviño (Aliber's brother) had the US Southern Homeopathic Medical Association ask SEP to send representatives to the Pan-American Homeopathic Congress in Florida in 1930 (Primer..., 1930). The secretary forwarded the invitation to the ENMH, whose faculty and students were struggling to rebuild the school after five years of inactivity and had no interest in establishing international connections. In 1933, the LMHI asked president Abelardo L. Rodriguez (1932-34) to be honorary president of the annual meeting in Madrid and to send representatives (Congresos..., 1934). The DPH recommended the president refrain from sending representatives and reject the honor because of the league's ties to the ELH. The DPH not only mentioned the school's continuing conflicts with the department and the SEP regarding diplomas, but also stated that the president's acceptance of the honorary title might imply a political endorsement of the school, along with the positions held by its faculty and students.

[If national authorities attend the meeting, Salubridad claimed,] Mexican homeopaths [who otherwise did not have funds to attend the meeting] would be represented, albeit indirectly, but these national homeopaths, most of them outlaws, proposed to maintain a medical school free from state regulations and to practice medicine without government surveillance (Congresos..., 1934, p.3). 
Mexican homeopaths also did not attend the 1933 LMHI annual meeting, and president Lázaro Cárdenas (1934-1940) similarly denied support for homeopaths wishing to attend the Pan-American Congress in Michigan in 1934 (Homeópatas EUA, 1934). These responses indicate that the DPH was aware of international mobilization by these practitioners and intentionally blocked their access to presidential and international support. Yet Cárdenas permitted the ELH-sponsored 1935 Homeopathic Pan-American Congress, the same event that the Union of Medical Doctors of the Federal District criticized so sharply (in the introduction to this article).

The reactions provoked by this meeting illustrate the continuing tensions surrounding professional regulations and the impact of foreign influences in the 1930s. Congress modified Article 3 of the Constitution in 1934, requiring education to be based on scientific thinking. The Cárdenas administration used the SEP to create a program which extended scientific education to the working class, and the ENMH joined several vocational schools within this program to train a qualified industrial class. In contrast, the 1934 Professional Congress banned membership to homeopaths, most of them ELH graduates. In short, while the state consistently sanctioned homeopathy by granting both public and private homeopathic schools official status, university physicians (most of whom staffed the university, DPH, and SEP) opposed state endorsement of homeopathic institutions. Within this context, the conditions under which Cárdenas welcomed the 1935 congress mirrored 1929, reminding university physicians of their vulnerable position (Homeópatas..., 1934; Organización..., 1934). This group consequently mobilized students, faculty, peasant unions, professional unions, and academic journals to make the Mexican public and international visitors aware of its members' view of homeopathy: a fraudulent, dogmatic, and anti-science therapeutic approach that thrived in Mexico despite the efforts of university doctors thanks to state sponsorship and international influence. Even in spite of these efforts by university physicians, homeopathic institutions retained their official status, proving that homeopath were effectively able to utilize the Mexican "cult of foreignness" to position homeopathy within Mexican medicine.

\section{Final considerations}

Homeopaths ruptured the boundaries of professional regulation in Mexico. As medicine was becoming professionalized in Mexico, homeopaths used foreign ties and influences to strengthen homeopathy's place amidst Mexican medical institutions and society. As physicians who studied in Mexico, homeopaths had conflicting views about foreign medical practitioners, practitioners with foreign medical degrees, national certifications, and questionable medical skill. They admired European homeopaths as well as their scholarship and products in the early nineteenth century, and shifted this admiration to US homeopaths at the turn of the twentieth, but they also believed that Mexican homeopaths should make their own contributions to advancing homeopathy and aligning homeopathic institutions with national professional standards. These ambivalent attitudes permeated all of Mexican society: patients and physicians, Mexicans and foreigners, citizens and state authorities. Some homeopaths took advantage of the 
Mexican cult of foreignness and used it to advance their position in the medical registry, with patients, among their professional peers, and with state authorities, consolidating their position in Mexican medicine.

The use of foreign support by homeopaths responded to the historical context. In the early nineteenth century, when Mexico had just obtained its independence and medical institutions were still forming, policies and regulations limited the ability of foreign homeopaths to obtain medical licenses. Professional liberalism in the second half of the century and the Porfiriato's openness to foreign influence gave homeopaths an opportunity to bring foreign homeopathic novelties to Mexican audiences. They translated foreign homeopathic texts, sold foreign homeopathic products, studied new therapeutic approaches in foreign medical schools, and they made their product and services available to Mexican patients. The nationalist sentiment that evolved after the Revolution reestablished policies and regulations that limited the practice of physicians with foreign degrees. However, graduates from the ELH had solidified as a professional group and mobilized their newly established international connections to influence domestic lawmakers and state authorities in supporting a new generation of homeopaths.

The internationalization of Mexican homeopaths ran parallel to the construction of the medical profession. Homeopaths wished to consolidate their institutions in Mexico, and used foreign credentials and support to do so, but they also aligned themselves with the trend to nationalize the medical profession. Very few foreign homeopaths (or homeopaths with foreign degrees) came to Mexico to practice during the Porfiriato and after the Revolution. Mexican doctors aimed to strengthen national medical institutions by controlling training and regulating practice, selectively discriminating against foreign practitioners, medical diplomas, and medical theories, and a group of homeopaths aligned themselves with this trend. Meanwhile, liberal homeopaths considered these approaches exclusivist and monopolistic, and used foreign therapeutic novelties and international support to generate domestic demand for homeopaths and pushed authorities to recognize Mexican homeopathic institutions as official. Their success in mobilizing international support shows how susceptible Mexican authorities were to international influence, as well as the limited control domestic physicians had over their own profession, opening the way for legally sanctioned medical pluralism. These mixed feelings about professional liberalism and professional control among Mexicans, both during the Porfiriato and after the Revolution, as well as their attitudes toward foreigners and foreign influence, played a key role in the regularization of homeopathic medicine in Mexico.

\section{ACKNOWLEDGMENTS}

I wish to thank the organizers of the 2016 Borderlands Symposium at Southwestern University, and the faculty and students who attended; their comments and questions pushed me to think beyond national contexts. I also would like to thank the three anonymous reviewers whose suggestions helped make this a stronger paper. 


\section{REFERENCES}

AGOSTONI, Claudia.

Enfermedad y persistencia de la medicina doméstica (1810-1910). In: Mayer, Alicia (coord.). México en tres momentos: 18101910-2010. Ciudad de México: Instituto de Investigaciones Históricas/Universidad Nacional Autónoma de México. p.77-89. 2007.

AGOSTONI, Claudia.

Monuments of progress: modernization and public health in Mexico City, 1876-1910. Calgary; Boulder: University of Calgary Press; University Press of Colorado. 2003.

AGOSTONI, Claudia.

Médicos científicos y médicos ilícitos en la ciudad de México durante el Porfiriato. Estudios de Historia Moderna y Contemporánea de México, v.19, p.13-31. 1999.

A LOS SEÑORES...

A los señores médicos homeópatas mexicanos. Homeoterapia, v.1, n.2, p.23. 1928.

ÁLVAREZ AMÉZQUITA, José.

Historia de la salubridad y de la asistencia en México. Ciudad de México: Secretaria de Salubridad y Asistencia. 1960.

ANTIGA, Juan.

México ante los Congresos Internacionales de Homeopatía. La Homeopatía, v.14, n.4, p.54-60. 1909.

ANTIGA, Juan.

El colegio médico del futuro. La Propaganda Homeopática, v.6, n.3, p.7-9. 1906.

ANTIGA, Juan.

Bioquímica. La Propaganda Homeopática, v.5, n.5, p.3-5. 1905.

ANTIGA, Juan.

¿Qué se necesita para formar buenos médicos homeópatas? La Homeopatía, v.10, n.8, p.113-117. 1904.

ARRIAGA, Juan N.

El progreso de la homeopatía en México, 1895-1911. In: Quinquennial Homeopathic International Congress, 8., 1911, London. Transactions... London: The Congress Committee. p.40-43. 1911.

AVISO...

Aviso del Departamento de Salubridad. Salubridad Pública, Ejercicio de la medicina, caja 4, exp. 16 (Archivo Histórico de la Secretaría de Salud Rómulo Velasco Ceballos, Ciudad de Mexico). 12 jun. 1923.

BARREDA, Gabino.

La homeopatía o juicio crítico sobre este nuevo medio de engañar a los Cándidos. Ciudad de México: Nabor Chavez. 1861.

BARRERA, José María. Carta., Salubridad Pública, Ejercicio de la medicina, caja 3, exp. 1 (Archivo Histórico de la Secretaría de Salud Rómulo Velasco Ceballos, Ciudad de Mexico). 10 Mar. 1841.

BAUER, Arnold J. Goods, power, history. New York: Cambridge University Press. 2001.

BIRN, Anne-Emmanuelle.

Marriage of convenience: Rockefeller International Health and revolutionary Mexico. Rochester: University of Rochester Press, 2012.

BUCHENAU, Jürgen.

Small numbers, great impact: Mexico and its immigrants, 1821-1973. Journal of American Ethnic History, v.20, n.3, p.23-49. 2001.

BUNKER, Steve.

Creating Mexican consumer culture in the age of Porfirio Díaz. Albuquerque: University of New México Press. 2012.

CARBÓ, José.

Petición. Consejo Superior de Salubridad legajo 31, exp. 1, p.1-4. (Archivo Histórico de la Antigua Escuela de Medicina, Ciudad de México). 30 Jan. 1854.

CARRILlO, Ana María.

Profesiones sanitarias y lucha de poderes en el México del siglo XIX. Asclepio, v.50, n.2, p.149168. 1998.

CEDILLO, E.

Bibliografía homeopática mexicana, desde el año de 1870 a 1919. Escuela Libre, v.1, n.3, 6, 7. 1919.

CLÍNICA...

Clínica San Rafael. La Propaganda Homeopática, v.7, n.1. 1907.

CNM.

Comisión Nacional Mexicana. Catálogo oficial de las exhibiciones de los Estados Unidos Mexicanos: Exposición Internacional de St. Louis, Missouri. 1904.

CONGRESO...

Congreso Homeopático de México. El Sol de Meissen, v.1, n.1, p.42-45. 1929.

CONGRESOS...

Fondo Abelardo L. Rodríguez. Congresos. Médico. España, Madrid (Liga Homeopática Internacional), 6/39 (Archivo General de la Nación, Ciudad de México). 1934. 
CUETO, Marcos.

Cold war, deadly fevers: malaria eradication in Mexico, 1955-1975. Baltimore: Woodrow Wilson Center Press; Johns Hopkins University Press. 2007.

CURSO...

Curso sistemático y práctico de bioquímica. $L a$ Propaganda Homeopática, v.5, n.4, p.16. 1905.

DE LA PEÑA, Carolyn Thomas.

The body electric: how strange machines built the modern American. New York: New York University Press. 2003.

DELGADO GARCÍA, Gregorio.

El doctor Juan Antiga y Escobar y la homeopatía en México. Boletín Mexicano de Historia y Filosofía de la Medicina, v.8, n.2, p.50-52. 2005.

DE REGRESSO...

De regreso de los Estados Unidos. La Propaganda Homeopática, v.5, n.13, p.4. 1905.

DIXIÈME CONGRÈS...

Dixième Congrès Quinquennial International d'Homeopathie. Paris. 1932.

DOCTOR...

Doctor Juan Antiga. La Propaganda Homeopática, v.4, n.4. 1904.

EN 1935...

En 1935, aun privan el fanatismo y los prejuicios. Acción Médica, n. especial, p.12. Oct. 1935.

FEW, Martha.

Circulating smallpox knowledge: Guatemalan doctors, Maya indians, and designing Spain's Royal Vaccination Expedition, 1780-1806. British Journal for the History of Science, v.43, n.4, p.519-537. 2010.

FRANÇOIS-FLORES, Francisco Darío.

Historia de la homeopatía en México. Ciudad de México: Biblioteca de Homeopatía de México. 2007.

FRANÇOIS-FLORES, Francisco Darío.

La Escuela Libre de Homeopatía. Ciudad de México: Biblioteca de Homeopatía de México. 2004.

FUENTES Y HERRERA, Pablo.

Homeopathy in Mexico. In: Transactions of the World's Homeopathic Convention. Philadelphia: American Institute of Homeopathy. p.383-390. 1876.

FUENTES Y HERRERA, Pablo.

Discurso. El Propagador Homeopático, v.1, n.10-11. 1872.

GARCÍA TREVIÑO, Eliud.

Carta al rector Ezequiel Adeato Chávez. Consejo Universitario, caja 13, exp. 92, f.1216 (Archivo Histórico de la Universidad Nacional Autónoma de México, Ciudad de México). 6 Oct. 1923.
GONZÁLEZ, Joaquín.

Historical sketch of homeopathy in Mexico. In: Transactions of the Fourth Quinquennial Session of the International Homeopathic Congress and the Forty Fourth Session of the American Institute of Homeopathy. Philadelphia: Sherman. p.995-1007. 1891.

GRAN CONSULTORIO...

Gran consultorio médico-hahnemaniano. $\mathrm{La}$ Propaganda Homeopática, v.4, n.4. 1904.

GURRÍA URGELL, Daniel.

Los médicos mexicanos y los invasores de la medicina. Medicina - Suplemento, v.5, n.54, p.1-4. 1924.

HALLER JR., John S.

The history of American homeopathy: the academic years, 1820-1935. Binghamton: The Haworth Press. 2005.

HAUSMAN, Gary.

Making medicine indigenous: homeopathy in South India. Social History of Medicine, v.15, n.2, p.303-322. 2002.

HERNÁNDEZ BERRONES, Jethro.

Homeopathy 'for Mexicans': medical popularisation, commercial endeavours, and patients' choice in the Mexican medical marketplace, 1853-1872. Medical History, v.61, n.4, p.568-589. 2017.

HERNÁNDEZ SÁENZ, Luz María.

Learning to heal: the medical profession in colonial Mexico, 1767-1831. New York: Peter Lang. 1997.

HERNÁNDEZ SÁENZ, Luz María.

Carving a niche: the medical profession in Mexico, 1800-1870. Montreal: McGill-Queen University Press. 2018.

HOMEÓPATAS...

Fondo Lázaro Cárdenas, Homeópatas, DF, Congreso, 433/81 (Archivo General de la Nación, Ciudad de México). 1934.

HOMEÓPATAS EUA.

Fondo Abelardo L. Rodríguez. Homeópatas, Estados Unidos (Chicago), Congreso Médico, 6/39-1 (Archivo General de la Nación, Ciudad de México). 1934.

HOSPITAL...

Fondo Emilio Portes Gil. Hospital Nacional Homeopático, 5/21 (Archivo General de la Nación, Ciudad de México). 1929.

JUÁREZ OCHOA, Benito; LÓPEZ SOTO, F.; BORJA, Desiderio.

Parte resolutiva del dictamen formulado por la primera comisión de gobernación de la ley reglamentaria del artículo $4^{\circ}$ constitucional. 
Salubridad Pública, Servicio Jurídico, caja 7, exp. 2 (Archivo Histórico de la Secretaría de Salud Rómulo Velasco Ceballos, Ciudad de México). 4 Nov. 1927.

JÜTTE, Robert.

The hidden roots: a history of homeopathy in Northern, Central, and Eastern Europe. Sttutgart: Institute for the History of Medicine/ Robert Bosch Foundation. 2006.

LAVALLE Y CARBAJAL, Eduardo.

A los médicos debe exigírseles título oficial u oficialmente revalidado. Gaceta Médica de México, v.8, n.9, p.135-225. 1913.

LIGA...

Liga Homeopática Mexicana. Carta a los diputados Alberto Bremauntz y Alberto Coria. Salubridad Pública, Ejercicio de la medicina, caja 13, exp. 14, p.56-60 (Archivo Histórico de la Secretaría de Salud Rómulo Velasco Ceballos, Ciudad de México). 20 Feb. 1934.

LIGA...

Liga Homeopática Mexicana. Carta al Dr. Aquilino Villanueva, director del Departamento de Salubridad. Salubridad Pública, Ejercicio de la medicina, caja 10, exp. 17, p.5-12 (Archivo Histórico de la Secretaría de Salud Rómulo Velasco Ceballos, Ciudad de México). 9 Apr. 1929.

LISTA...

Lista de los médicos cirujanos alópatas y homeópatas, farmacéuticos, parteras, cirujanos dentistas, médicos veterinarios, legalmente autorizados, residentes en el Distrito Federal y que han presentado sus títulos al Consejo Superior de Salubridad. Salubridad Pública, Ejercicio de la medicina, caja 4, exp. 1 (Archivo Histórico de la Secretaría de Salud Rómulo Velasco Ceballos, Ciudad de México). 1907.

MANUELL, R.E.

Discurso pronunciado por su autor, en la sesión celebrada en el anfiteatro de la Escuela Preparatoria, el 6 de marzo de 1912. Gaceta Médica de México. v.7, n.49, p.121-130. 1912.

MARTÍNEZ CORTÉS, Fernando.

La medicina científica y el siglo XIX mexicano. Ciudad de México: Fondo de Cultura Económica. Available at: <http:// bibliotecadigital.ilce.edu.mx/sites/ciencia/ volumen1/ciencia2/45/htm/medicina.htm $>$. Access on: 6 June 2012. 1997.

MCCREA, H.L.

Diseased relations: epidemics, public health, and State-building in Yucatán, Mexico, 1847-1924. Albuquerque: University of New Mexico Press. 2010.
MÉDICOS...

Médicos, cirujanos, farmacéuticos, dentistas, flebotomianos, y parteras. La Sociedad, p. 2.25 Feb. 1859.

MENDIZABAL, Gregorio.

Discurso del doctor Gregorio Mendizabal. Asociación Médica Mexicana: Boletín de Propaganda, v.1, n.1, p. 16-26. 1920.

MÉXICO.

Secretaría de Educación Pública. Decreto por el cual se reglamente el funcionamiento de las escuelas libres. Diario Oficial de la Nación, v.57, n.18, p.7-8. 23 Nov. 1929.

\section{MÉXICO.}

Legislación mexicana, ó, colección completa de las disposiciones legislativas expedidas desde la independencia de la República. Ciudad de México: Dublán y Lozano. 1876.

NAVARRETE, Rafael.

Petición. Salubridad Pública, Ejercicio de la medicina, caja 14, exp. 21 (Archivo Histórico de la Secretaría de Salud Rómulo Velasco Ceballos, Ciudad de México). n.d.

NO UN ALIVIO...

No un alivio temporal sino una restauración permanente. La Propaganda Homeopática, v.5, n.13, p.16. 1905.

OCARANZA, Fernando; CUEVAS, José A. Comunicación. Consejo Universitario, caja 16, exp. 106, docs.1537-1538, f.14-17 (Archivo Histórico de la Universidad Nacional Autónoma de México, Ciudad de México). Nov. 1925.

ORGANIZACIÓN...

Organización del Congreso Panamericano de Homeopatía, legajo 167, exp. 2, f.40-42 (Archivo Histórico de la Antigua Escuela de Medicina, Ciudad de México). 1934.

PALAVICINI, Félix.

Comunicación a la Universidad Nacional. Beneficencia Pública, Hospital Nacional Homeopático, legajo 1, exp. 29, f.8 (Archivo Histórico de la Secretaría de Salud Rómulo Velasco Ceballos, Ciudad de México). n.d.

PALMER, Steven.

From popular medicine to medical populism: doctors, healers, and public power in Costa Rica, 1800-1940. Durham: Duke University Press. 2003.

PANOS, Maesimund B.; DESROSIERS, Della P. (Comp.).

The Homeopathic Recorder and Proceedings of the International Hahnemannian Association: cumulative indices, 1881-1959. Tipp City, Ohio: Woodward Foundation. 1989. 
PORRAGAS, Luis.

Carta al rector Ezequiel Adeato Chávez. Consejo Universitario, caja 13, exp. 92, doc. 1217 (Archivo Histórico de la Universidad Nacional Autónoma de México, Ciudad de México). 6 Oct. 1923.

PORRAGAS, Luis.

Carta al Director de la Beneficencia Pública. Beneficiencia Pública, HNH, legajo 1, exp. 19 (Archivo Histórico de la Secretaría de Salud Rómulo Velasco Ceballos, Ciudad de México). 10 Mar. 1914

PRIEGO, Natalia.

Ciencia, historia y modernidad: la microbiología en México durante el Porfiriato. Madrid: Consejo Superior de Investigaciones Científicas. 2009.

PRIMER CONGRESO...

Primer Congreso Homeopático Panamericano. Secretaría de Educación Pública, Departamento de Psicopedagogía e Higiene, 35564, 4-9-4144. (Archivo General de la Nación, Ciudad de México). 1930.

REGISTRO...

Registro de títulos de médicos homeópatas. Dirección General de Asuntos Jurídicos (Archivo Histórico de la Secretaría de Salud Rómulo Velasco Ceballos, Ciudad de México). n.d.

REGLAMENTACIÓN...

Reglamentación de las profesiones. Medicina: Suplemento, v.17, n.293-294, p.71-78, 80-86. 1937.

REGLAMENTO...

Reglamento del art. $4^{\circ}$ constitucional.

Proyecto. Asociación Médica Mexicana: Boletín de

Propaganda, v.2, n.2, p.25-27. 1922.

RESPUESTA...

Respuesta del Consejo Superior de Salubridad. Salubridad Pública, Ejercicio de la medicina, caja 2, exp. 36 (Archivo Histórico de la Secretaría de Salud Rómulo Velasco Ceballos, Ciudad de México). 1855.

REVALIDACIÓN...

Revalidación de estudios. Consejo Universitario caja 1, exp. 1-6 (Archivo Histórico de la Universidad Nacional Autónoma de México, Ciudad de México). 1911.

SANCHIZ, Narciso.

Carta a José Noriega. Salubridad Pública, Ejercicio de la medicina, caja 3, exp. 25 (Archivo Histórico de la Secretaría de Salud Rómulo Velasco Ceballos, Ciudad de México). 18 Jan. 1855.

SECRETARÍA...

Secretaría de Educación Pública. Salubridad Pública, Ejercicio de la medicina, caja 4, exp.
7 (Archivo Histórico de la Secretaría de Salud Rómulo Velasco Ceballos, Ciudad de México). 30 May 1922.

\section{SEGUNDA SESIÓN}

Segunda sesión. Consejo Universitario, 19101930, саја 9, exp. 72, doc. 997-998, p.14-18.

(Archivo Histórico de la Universidad Nacional Autónoma de México, Ciudad de México). 20 Jan. 1922.

\section{SINDICATO...}

Fondo Emilio Portes Gil, Sindicato de Médicos Homeópatas, 2/3 (Archivo General de la Nación, Ciudad de México). 1929.

SOLICITUD...

Solicitud. SP, EM, 3, 63, 71 (Archivo General de la Nación, Ciudad de México). Aug. 1871.

SOLÓRZANO, Armando.

La influencia de la Fundación Rockefeller en la conformación de la profesión médica mexicana, 1921-1949. Revista Mexicana de Sociología, v.58, n.1, p.173-203. 1996.

SOWELL, David.

The tale of healer Miguel Perdomo Neira: medicine, ideologies, and power in the nineteenth-century Andes. Wilmington: SR Books. 2001.

TRANSACTIONS...

Transactions of the Ninth Quinquennial

International Homeopathic Congress. London: John Bale. 1927.

UNA CARTA...

Una carta interesante. La Propaganda

Homeopática, v.5, n.4, p.9-10. 1905.

VÁZQUEZ VELA, Gonzalo.

Comunicación con el jefe del Departamento de Salubridad. SP, EM, 14, 8 (Archivo General de la Nación, Ciudad de México). 14 Feb. 1938.

VINYALS, Augustus.

El momento actual y la homeopatía. El Sol de Meissen, v.1, n.1, p.11-17. 1929.

YANKELEVICH, Pablo.

Extranjeros indeseables en México (1911-1940): una aproximación cuantitativa a la aplicación del artículo 33 constitucional. Historia Mexicana, v.53, n.3, p.693-744. 2004.

WEBER, Beatriz Teixeira.

Percalços da história da homeopatia no Brasil no século XIX. In: Isaia, Artur Cesar, Priego, Natalia Priego. História, ciência e medicina no Brasil e América Latina (séculos XIX e XX). Canoas: Unilasalle. p.223-246. 2016.

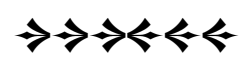

